\title{
The Relationship Between Characteristics of Health Workers on Handwashing Behavior
}

\author{
Ossy Wijaya Iriandoko ${ }^{1}$, Djazuly Chalidyanto ${ }^{2}$ \\ Correspondence Author : ossy.wijaya.iandoko-2019@fkm.unair.ac.id \\ ${ }^{1}$ Department of Administration and Health Policy, Faculty of Public Health, University of Airlangga, Indonesia \\ 2Department of Administration and Health Policy, Faculty of Public Health, University of Airlangga, Indonesia
}

\section{N D E X I N G}

Keywords:

Characteristic;

Health Workers;

Level of Compliance;

Handwashing.

Kata kunci:

Karakteristik;

Tenaga Medis;

Tingkat Kepatuhan;

Cuci tangan.

\begin{abstract}
A B S T R AC T
Based on data from PPI Hospital X in Surabaya there are still nosocomial infections. If the incidence of this infection continues to recur, then the hospital's image will be bad and can cause hospital bed occupational rates to decrease. The purpose of this study was to determine the relationship between the characteristics of health workers (level of knowledge, level of education, age, and length of work) with the level of compliance of health workers doing hand washing at the "X" Hospital in Surabaya. This research is a descriptive correlation study. The sample in this study was 150 health workers working at X Hospital Surabaya, using proportional random sampling stratification technique. Data were collected using a questionnaire instrument. Data analysis using Pearson correlation test. The results revealed a significant relationship between the level of knowledge about handwashing ( $p=0.001)$, an education level ( $p$ $=0.004)$, age $(p=0,000)$ and years of service $(p=0,000)$ to the level of compliance of health workers doing hand washing at the "X" Hospital in Surabaya. Surabaya "X" Hospital health workers have a level of compliance with handwashing with a maximum compliance category $>75 \%(76 \%)$.
\end{abstract}

Berdasarkan data dari PPI Rumah Sakit X di Surabaya masih terdapat kejadian infeksi nosokomial. Jika kejadian infeksi ini terus berulang, maka citra rumah sakit akan buruk dan bisa mengakibatkan Bed Occupational Rate rumah sakit menurun. Tujuan penelitian ini untuk mengetahui hubungan karakteristik tenaga kesehatan (tingkat pengetahuan, tingkat pendidikan, umur dan lama bekerja) dengan tingkat kepatuhan tenaga kesehatan melakukan cuci tangan di Rumah Sakit " $X$ " Surabaya. Penelitian ini merupakan penelitian deskriptif korelasi. Sampel dalam penelitian ini adalah tenaga kesehatan yang bekerja di Rumah Sakit X Surabaya sebanyak 150 orang, dengan menggunakan teknik stratifikasi proporsional random sampling. Data dikumpulkan dengan menggunakan instrumen kuesioner. Analisis data menggunakan uji pearson correlation. Hasil penelitian menyatakan adanya hubungan yang signifikan antara tingkat pengetahuan mengenai cuci tangan $(p=0,001)$, tingkat pendidikan $(p=0,004)$, usia $(p=0,000)$ dan masa kerja $(p=0,000)$ terhadap tingkat kepatuhan tenaga kesehatan melakukan cuci tangan) di Rumah Sakit " $X$ " Suarabaya. Tenaga kesehatan Rumah Sakit "X" Surabaya mempunyai tingkat kepatuhan melakukan cuci tangan dengan kategori kepatuhan maksimal >75\% (76\%).

(C) 2020 JMMR. All rights reserved

\section{INTRODUCTION}

The prevalence of nosocomial infections in developing countries including Indonesia is an average of $9.1 \%$ with variations of $6.1 \%-16.0 \%$ (Soeroso S, 2003). Nosocomial infections in Indonesia occur in several types/types of hospitals. The Ministry of Health of the Republic of Indonesia conducted a study in 2004 with data on the proportion of nosocomial infections in government hospitals with 1,527 patients out of 160,417 patients $(55.1 \%)$, while in private hospitals with 991 patients out of at-risk patients 130,047 (35.7\%). Whereas in military hospitals with 254 patients out of 1,672 (9.1\%) patients.

Policies to prevent nosocomial infections in hospitals and other health facilities have been issued by the Government of Indonesia. The policy was written in Minister of Health 
Decree Number 270/Menkes/III/2007 concerning Managerial Guidelines for Infection Control in Hospitals and Health Facilities. Also, Minister of Health Decree No. 381/Menkes/III/2007 concerning Guidelines for Infection Control in Hospitals and Health Facilities. The incidence of nosocomial infections is used as an indicator of the quality of hospital services. An operational permit for a hospital can be obtained if the number of nosocomial infections is high (Darmadi, 2008).

The most effective method to prevent nosocomial infections is to do Universal Precaution, one of which is washing hands every time you take action on a patient in the hospital. This is in line with what was stated by Larson et al (Larson et al., 2000) that one of the most important ways to minimize nosocomial infections is proper hand hygiene because the majority of nosocomial infections are transferred through the hands of medical personnel (Paudel et al., 2017). Health workers are people who make direct contact with patients. The health workers' hands are in close contact with patients and they can contaminate patients by providing daily care including touching, listening, and through instruments (Kampf \& Löffler, 2010). This is what makes health workers play a role in nosocomial infections (Taherri, 2007). A study has shown that washing hands can reduce $20 \%-40 \%$ incidence of nosocomial infections. However, the implementation of handwashing itself has not yet received an optimal positive response.

In developing countries, failure is often found in the implementation of handwashing due to limited funds in providing handwashing facilities. However, when funds are available, the next problem that is very worrying is the low level of compliance to comply with procedures, even though it is one of the important ethical and professional tasks of health professionals protecting patients by adhering to the principles of health workers (Sharif et al., 2016). Hand hygiene improvement is done to minimize the occurrence of nosocomial infections, is a high priority of the World Health Organization (WHO) (Fesharaki et al., 2014). Institutional hand hygiene protocols reveal that hand hygiene must be implemented both before and after contact with patients and before and after invasive procedures (Helder et al., 2012).

Research in the United States shows the level of compliance of health workers in doing hand washing is still around $50 \%$ while in Australia it is still around $65 \%$. Similar to the handwashing program at "X" Hospital Surabaya which began in 2008, but until now the compliance of health workers doing hand washing is only around $60 \%$. This is a challenge for the hospital infection control team to promote the handwashing program.

The results of (Taadi et al., 2019) state that washing hands can reduce $20 \%-40 \%$ of the incidence of nosocomial infections, but the implementation of hand washing has not been responded to optimally. Several attempts have been made by the hospital to improve hand washing behavior, both for teachers, facilities, and patients/families. However, there are still obstacles, namely the lack of compliance with procedures (Saragih \& Rumapea, 2012). Washing hands is an important activity for the environment where clients are treated. Routine hand washing is an inexpensive and important activity in controlling infection, especially in preventing the transmission of microorganisms (Rikayanti \& Arta, 2014). Hand washing should be carried out in accordance with standard procedures to prevent the multiplication of germs. Washing hands properly must be in accordance with 6 steps of washing hands and in accordance with five hand washing moments. The accuracy of the 
duration of washing hands with soap and running water is 40-60 seconds when using a hand rub is 20-30 seconds (Iskandar \& Yanto, 2018). However, in reality, even though health workers have received health education about hand washing, the compliance of the patient's family in carrying out the 6-step hand washing is still not optimal.

Health workers who work in hospitals have different characteristics, in terms of the level of knowledge, education level, age, and length of work. This difference in characteristics is certainly a factor that can influence the mastery of knowledge, skills, and professional attitudes of a health worker in carrying out his role.

"X" Hospital Surabaya is a private hospital in the city of Surabaya. This hospital provides several medical services, namely inpatient units, outpatient units, emergency departments, operating rooms, intensive care units (ICU), neonatal intensive care units (NICU), nurseries, executive health screening, chemotherapy, hemodialysis, and units support such as radiology, laboratory, physiotherapy, and pharmaceutical units. In controlling the incidence of nosocomial infections, the Surabaya "X" Hospital has a Hospital Infection Control Prevention Committee. Hospital Infection Control Prevention Committee has programmed prevention and control of nosocomial infections, the program can be in the form of training or direct supervision to the health workers' room.

According to data from PPI Hospital "X" Surabaya still found nosocomial infections. If these infections continue to occur repeatedly, the image of the hospital will be bad so that patients will be reluctant to come to the "X" Hospital in Surabaya and then will reduce the hospital's BOR (Bed Occupational Rate). If the hospital's BOR continues to decline, the hospital can be closed and unable to operate again because of insufficient funds, otherwise there will be a Termination of Employment of employees to increase the number of unemployed.

Based on the explanation above, researchers are interested in conducting research related to the relationship between the characteristics of health workers with the compliance of health workers doing hand washing at the Surabaya "X" Hospital. This research was conducted to analyze the relationship between the characteristics of health workers with the level of compliance of health workers doing hand washing at the Surabaya "X" Hospital, to illustrate the relationship between knowledge, education level, age, and years of service of health workers with the level of compliance of health workers doing hand washing at home Hospital "X" Surabaya, as well as to illustrate the level of compliance of health workers doing hand washing in Surabaya "X" Hospital.

\section{RESEARCH METHOD}

This research is a descriptive correlation study which is a study conducted to find out the relationship between 2 research variables, namely between the independent variable (free) characteristics of health workers (knowledge, education, age, years of service) with the dependent variable (bound) compliance of health workers doing hand washing.

The approach used is cross-sectional because the measurement of research data is done at the same time/moment. The study was conducted at the "X" Hospital in Surabaya. The reason the researchers chose this location was that there had never been a study of the relationship between the characteristics of health workers with the level of compliance of health workers doing hand washing at Surabaya "X" Hospital. 
The population in this study were all health workers in Surabaya "X" Hospital, with a total of 750 people including medical personnel; clinical psychology staff; nurses; midwifery staff; pharmaceutical staff; community health workers; environmental health workers; nutrition worker; physical power ignition; medical technicians; biomedical engineering personnel; traditional health workers; and other health workers. The number of samples in this study was $20 \%$ of the total population of 150 people, according to Arikunto's opinion that a population of more than one hundred people could be sampled $15 \%$ to $30 \%$. The sampling technique uses proportional random sampling stratification given that the health center in this study consisted of several groups.

Data collection was carried out with a questionnaire consisting of two questionnaires, namely the questionnaire of labor characteristics covering age, sex, education, and length of work. The second sheet is a questionnaire sheet about compliance with washing hands. Data analysis in this study used the Pearson correlation test, to determine the effect of labor characteristics on handwashing compliance. Declared influential if the value of sig. (2-tailed) $<0.05$.

\section{RESULT AND DISCUSSION}

The following results are based on the results of the questionnaire and the results of data processing that have been analyzed using Pearson correlation analysis.

\section{Characteristics of Respondents}

Table. 1 Distribution of Respondents' Characteristics at Surabaya "X" Hospital in 2020 $(n=150)$

\begin{tabular}{|l|c|c|}
\hline \multicolumn{1}{c|}{ Characteristic } & Frequency (n) & Percentage (\%) \\
\hline 1. Level of Knowledge: & 30 & $20 \%$ \\
Low & 36 & $24 \%$ \\
Moderate & 84 & $56 \%$ \\
High & 150 & $100 \%$ \\
Total & & $33,3 \%$ \\
\hline 2. Education Level: & 50 & $66,7 \%$ \\
Diploma III & 100 & $100 \%$ \\
Bachelor & 150 & $30 \%$ \\
Total & & $22 \%$ \\
\hline 3. Age Category: & 45 & $48 \%$ \\
20-25 years old & 33 & $100 \%$ \\
25-30 years old & 72 & \\
>30 years old & 150 & $24 \%$ \\
Total & & $26 \%$ \\
\hline 4. Length of Work: & 36 & $50 \%$ \\
1-5 years & 39 & $100 \%$ \\
6-10 years & 75 & $24 \%$ \\
>10 years & 150 & $76 \%$ \\
Total & & $100 \%$ \\
\hline 5. Compliance Level: & 36 & 114 \\
Not comply & 150 & \\
Complied & & \\
Total & & \\
\hline Source Data Aalyed & & \\
\hline
\end{tabular}

Source: Data Analyzed (2020) 
Based on Table.1, it is known that the majority of respondents have a high level of knowledge about hand washing as many as 84 respondents $(56 \%)$, followed by moderate knowledge as many as 36 respondents (24\%) and as many as 30 respondents have low knowledge of hand washing (20\%). This shows that most respondents already understand about washing hands. Washing hands is an indicator of a clean and healthy lifestyle that is important to understand and do. The level of knowledge can be influenced by the level of education of the respondents. The majority of respondents had an undergraduate education level of $66.7 \%$. The results of this study are not in line with research conducted by Lestari regarding the relationship between knowledge and attitudes towards hand washing behavior in the community of Pegirian village. Sustainable research shows that the majority of respondents' knowledge about hand washing is still not good enough. There were respondents with poor knowledge, namely $70.2 \%$. This shows that there are still many people who do not understand about hand washing (Lestari, 2019).

Based on education level, it can be seen that the majority of respondents have a bachelor's education as many as 100 respondents $(66.7 \%)$, while respondents who have a diploma III last education are 50 respondents (33.3\%). According to Hartono (2015), the desired formal and non-formal education is a change in ability, appearance, and behavior. According to (Notoatmodjo, 2010), the higher a person's education, the easier it is to accept new things and easily adjust to these new things. According to (Rikayanti \& Arta, 2014), education is an effort to develop personality and abilities inside and outside the school and lasts a lifetime. Education affects the learning process, the higher a person's education, the easier it is for that person to receive information. With higher education, someone will tend to get information, both from other people and from the mass media. The more information that comes in, the more knowledge will be gained about health. According to (Damanik, 2012) states that the longer someone who is in the field of work, the more skilled people work.

Based on age category, it can be seen that the majority of respondents aged $>30$ years were 72 respondents (48\%), followed by respondents aged $20-25$ years as many as 45 respondents $(30 \%)$, and those aged $26-30$ years were 33 respondents $(22 \%)$. The results of this study are different from the results of previous studies regarding washing the hands of health care workers. The results showed that nurses with a working period of fewer than five years had the highest level of compliance (77.78\%) (Saragih \& Rumapea, 2012). The level of discipline of health workers based on age according to (Saragih \& Rumapea, 2012) explains that age affects a person's mindset, and thought patterns affect one's behavior. Broadly speaking, a person's age is an indicator in making decisions that refer to each of his experiences, with the more age he receives instructions and in carrying out a procedure the more responsible and experienced he becomes. The more mature a person is in thinking and acting (Saragih \& Rumapea, 2012).

Based on the table above, it can be seen that the majority of respondents have worked in Surabaya "X" Hospital for> 10 years by 75 respondents (50\%), followed by respondents who have worked for $6-10$ years as many as 39 respondents $(26 \%)$, and the last are respondents with a work period of $1-5$ years as many as 34 respondents (24\%). Usually, the length of the service period is used to measure the loyalty of an employee, the longer the work period, the more loyalty the employee will be to the company. So important is loyalty 
that the company feels the need to formulate various "rewarding" policies by incorporating long-working factors, for example awarding employees who have worked for many years, getting additional leave for employees who have worked for many years, and others. Loyal is obedient, loyal. By gaining loyalty from its employees, a company feels that it really has employees who are ready to fight for the sake of their business, likewise, if an employee is sure that he has given loyalty, he doesn't have to worry about losing his job. But many companies consider that loyalty is the second thing that is expected of an employee after professionalism (Saragih \& Rumapea, 2012).

Based on compliance level, it can be seen that the majority of respondents complied to wash their hands as many as 114 respondents (76\%), while those who did not comply were only a small proportion of 36 respondents (24\%). Nurbaiti (2007) suggests that compliance can be influenced by internal and external factors such as age, education, knowledge and tenure supported by Notoadmodjo, who argues that the factors that affect compliance are education, age, and motivation (Saragih \& Rumapea, 2012).

\section{Cross Tabulation}

Table.2 Distribution of Cross Tabulation Level of Knowledge of Health Workers on Hand Washing with Compliance Level of Health Workers Doing Hand Washing at "X" Hospital Surabaya in $2020(n=150)$

\begin{tabular}{|c|c|c|c|c|c|c|c|}
\hline \multirow{3}{*}{$\begin{array}{l}\text { Level of Knowledge } \\
\text { of Health Workers }\end{array}$} & \multicolumn{4}{|c|}{$\begin{array}{c}\text { Level of Health Workers Compliance } \\
\text { Hand Washing }\end{array}$} & \multirow{3}{*}{$\begin{array}{l}\text { Frequency } \\
\quad(\mathbf{n})\end{array}$} & \multirow{3}{*}{$\begin{array}{l}\text { Percentage } \\
\quad(\%)\end{array}$} & \multirow{3}{*}{$\begin{array}{c}\text { Sig. } \\
\text { (2-tailed) }\end{array}$} \\
\hline & \multicolumn{2}{|c|}{ Complied } & \multicolumn{2}{|c|}{ Not Comply } & & & \\
\hline & $\mathrm{n}$ & $\%$ & $\mathbf{n}$ & $\%$ & & & \\
\hline Low & 8 & $5,3 \%$ & 22 & $14,7 \%$ & 30 & $20 \%$ & 0,001 \\
\hline Moderate & 24 & $16 \%$ & 12 & $8 \%$ & 36 & $24 \%$ & \\
\hline High & 82 & $54,7 \%$ & 2 & $1,3 \%$ & 84 & $56 \%$ & \\
\hline Total & 114 & $76 \%$ & 36 & $24 \%$ & 150 & $100 \%$ & \\
\hline
\end{tabular}

Source: Data Analyzed (2020)

Based on Table.2, it is known that health workers with a high level of knowledge have the highest level of compliance $(54.7 \%)$, followed by a moderate level of knowledge $(16 \%)$ and a low level of knowledge (5.3\%). Pearson correlation test analysis showed the value of sig. (2-tailed) of 0.001 which is smaller than 0.05 so it is stated that the level of knowledge of health workers has a significant effect on the level of compliance of health workers doing hand washing.

Table.3 Distribution of Cross Tabulation Level of Education of Health Workers with Compliance Level of Health Workers Doing Hand Washing at "X" Hospital Surabaya in $2020(n=150)$

\begin{tabular}{|c|c|c|c|c|c|c|c|}
\hline \multirow{3}{*}{$\begin{array}{l}\text { Education Level of } \\
\text { Health Workers }\end{array}$} & \multicolumn{4}{|c|}{$\begin{array}{c}\text { Level of Health Workers Compliance } \\
\text { Hand Washing }\end{array}$} & \multirow{3}{*}{$\begin{array}{l}\text { Frequency } \\
\quad(\mathbf{n})\end{array}$} & \multirow{3}{*}{$\begin{array}{l}\text { Percentage } \\
(\%)\end{array}$} & \multirow{3}{*}{$\begin{array}{c}\text { Sig. } \\
\text { (2-tailed) }\end{array}$} \\
\hline & \multicolumn{2}{|c|}{ Complied } & \multicolumn{2}{|c|}{ Not Comply } & & & \\
\hline & $\mathrm{n}$ & $\%$ & $\mathbf{n}$ & $\%$ & & & \\
\hline Diploma III & 31 & $12,7 \%$ & 19 & $20,7 \%$ & 50 & $33,3 \%$ & 0,004 \\
\hline Bachelor & 83 & $55,3 \%$ & 17 & $11,3 \%$ & 100 & $66,7 \%$ & \\
\hline Total & 114 & $76 \%$ & 36 & $24 \%$ & 150 & $100 \%$ & \\
\hline
\end{tabular}

Source: Data Analyzed (2020) 
Based on Table.3, it is known that health workers with a Bachelor's level of education have the highest level of compliance as many as 83 respondents $(55.3 \%)$, while health workers with a Diploma III education level are 31 respondents $(12.7 \%)$. Pearson correlation test analysis showed a sig. (2-tailed) value of 0.004 which was smaller than 0.05 so that it was stated that the level of education of health workers had a significant effect on the level of compliance of health workers doing hand washing.

Table.4 Distribution of Cross Tabulation Age of Health Workers by Compliance Level of Health Workers Doing Hand Washing at

"X" Hospital Surabaya in $2020(\mathrm{n}=150)$

\begin{tabular}{|c|c|c|c|c|c|c|c|}
\hline \multirow{3}{*}{$\begin{array}{l}\text { Age of Health } \\
\text { Workers }\end{array}$} & \multicolumn{4}{|c|}{$\begin{array}{c}\text { Level of Health Workers Compliance } \\
\text { Hand Washing }\end{array}$} & \multirow{3}{*}{$\begin{array}{l}\text { Frequency } \\
\quad(\mathbf{n})\end{array}$} & \multirow{3}{*}{$\begin{array}{l}\text { Percentage } \\
(\%)\end{array}$} & \multirow{3}{*}{$\begin{array}{c}\text { Sig. } \\
\text { (2-tailed) }\end{array}$} \\
\hline & \multicolumn{2}{|c|}{ Complied } & \multicolumn{2}{|c|}{ Not Comply } & & & \\
\hline & $\mathrm{n}$ & $\%$ & $\mathrm{n}$ & $\%$ & & & \\
\hline $20-25$ years old & 19 & $12,7 \%$ & 26 & $17,4 \%$ & 45 & $30 \%$ & 0,000 \\
\hline $26-30$ years old & 25 & $16,7 \%$ & 8 & $5,3 \%$ & 33 & $22 \%$ & \\
\hline$>30$ years old & 70 & $46,6 \%$ & 2 & $1,3 \%$ & 72 & $48 \%$ & \\
\hline Total & 114 & $76 \%$ & 36 & $24 \%$ & 150 & $100 \%$ & \\
\hline
\end{tabular}

Source: Data Analyzed (2020)

Furthermore, based on Table 4, it is known that health workers aged $>30$ years showed the highest percentage of compliance $(46.6 \%)$, followed by health workers aged 26-30 years $(16.7 \%)$ and health workers aged $20-25$ years $(12.7 \%)$. Pearson correlation test analysis showed a sig. (2-tailed) value of 0,000 which was smaller than 0.05 so it was stated that the age of health workers had a significant effect on the level of compliance of health workers doing hand washing. The following are the results of the cross-tabulation of the age of health workers with the level of compliance of health workers doing hand washing in Surabaya "X" hospitals in 2020.

Table.5 Distribution of Cross Tabulation Work Periods of Health Workers with Compliance Level Health Workers Perform Handwashing at "X" Hospital Surabaya in 2020 (n=150)

\begin{tabular}{|c|c|c|c|c|c|c|c|}
\hline \multirow{3}{*}{$\begin{array}{l}\text { Duration of Health } \\
\text { Workers }\end{array}$} & \multicolumn{4}{|c|}{$\begin{array}{c}\text { Level of Health Workers Compliance } \\
\text { Hand Washing }\end{array}$} & \multirow{3}{*}{$\begin{array}{l}\text { Frequency } \\
\quad(\mathrm{n})\end{array}$} & \multirow{3}{*}{$\begin{array}{l}\text { Percentage } \\
\quad(\%)\end{array}$} & \multirow{3}{*}{$\begin{array}{c}\text { Sig. } \\
\text { (2-tailed) }\end{array}$} \\
\hline & \multicolumn{2}{|c|}{ Complied } & \multicolumn{2}{|c|}{ Not comply } & & & \\
\hline & $\mathrm{n}$ & $\%$ & $\mathrm{n}$ & $\%$ & & & \\
\hline $1-5$ years & 14 & $9,3 \%$ & 22 & $14,7 \%$ & 46 & $24 \%$ & 0,000 \\
\hline $6-10$ years & 29 & $19,3 \%$ & 10 & $6,7 \%$ & 39 & $26 \%$ & \\
\hline$>10$ years & 71 & $47,4 \%$ & 4 & $2,6 \%$ & 75 & $50 \%$ & \\
\hline Jumlah & 114 & $76 \%$ & 36 & $24 \%$ & 150 & $100 \%$ & \\
\hline
\end{tabular}

Source: Data Analyzed (2020)

Based on Table.5, it is known that health workers who have worked more than 10 years have the highest level of compliance with 71 respondents $(47.4 \%)$, followed by health workers with $6-10$ years of service with 29 respondents $(19.3 \%)$ and health workers who worked $1-5$ years as many as 14 respondents $(9.3 \%)$. Pearson correlation analysis shows a sig. (2-tailed) value of 0,000 which is smaller than 0.05 so that it is stated that the length of work 
of the health worker has a significant effect on the level of compliance of health workers doing hand washing.

\section{Discussion}

Characteristics of Health Workers at Surabaya "X" Hospital Hand washing Knowledge

The results of the study prove that the majority (56\%) of health workers have high knowledge related to hand washing. Knowledge is the result of knowing that occurs after someone senses a certain object. The majority of human knowledge is gained through the eyes and ears (Notoatmodjo, 2010). Knowledge is information or information that someone knows or realizes. Factors that can influence knowledge include education, media, and information. Education is a change in the attitudes and behavior of individuals or groups as well as efforts to mature humans by trying to teach and train in the context of educating. The media is specifically designed to reach the wider community, information as knowledge transfer.

\section{Education}

The results of the study prove that the majority of the education level of health workers in Surabaya "X" Hospital is Bachelor (66.7\%), while those who have Diploma III education are only a small proportion (33.3\%). At present, the basis for structuring the education of health workers is towards the order of professionalism and globalization. Professionalism requires health workers to complete academic education and professions like other developing professions. Low education of health workers can be low health services and competitiveness of health workers with foreign health workers.

The International Council of Nursing (ICN) requires health workers who will provide mandatory medical services through certification and competency tests to obtain the Nurse Register (RN). For an RN test, a person must graduate, so that the standard of basic education for international health workers must be educated. Likewise, with the regulation of health workers in the country, many foreign health workers will enter Indonesia, which has higher competency standards. If this is not anticipated then the presence of foreign health workers will become a threat to Indonesian health workers. So, the awareness of Surabaya "X" Hospital health workers is demanded to consider the continuation of their education so that their presence in health services in the current era of globalization can be maintained and increased. Hospital management is also expected to provide attention and support for health workers who want to increase their education level.

\section{Age}

The results of the study prove that the majority of health workers in the Surabaya "X" Hospital are in the age range> 30 years $(48 \%)$. This shows that health workers at Surabaya "X" Hospital are in the adult age range, according to Peaget, at an adult age, a person is more flexible, open, and very adaptable. To support the development of Surabaya "X" hospitals, especially in health services, where human resources are in a position that is very possible to be invited to jointly improve the quality of services, especially health services. However, it cannot be denied that at this age one's loyalty is still focused on oneself this can be 
understood because workers at this age are still strongly motivated to strengthen their existence if they need to move from one organization to another organization or even move from one profession. to another profession (Bujuri, 2018). Therefore, the management of the hospital must be careful to see this condition so that they can retain their employees.

\section{Length of Work}

The results of the research prove that the majority of Surabaya X's Hospital health workers have worked> 10 years (50\%). Generally, the length of service is used to measure the loyalty of a health worker, the longer the work period, the more loyal the health worker is to the institution. Loyalty is very important, so hospitals need to develop a variety of "rewarding" policies by including long-time work factors, such as awarding rewards to health workers who have worked for many years, obtaining additional leave for health workers who have worked for years and so on.

With the loyalty that is in the health workers of a hospital feel have a health worker who is ready to fight for the common interest, as well as if a health worker is sure to have given loyalty, he does not need to worry about losing his job. But not a few institutions assume that loyalty is the second thing expected of an employee after professionalism. In this situation it can be mentioned that the health workers of the "X" Hospital in Surabaya showed a high level of loyalty towards the hospital, where the results of this study showed that there were more health workers who were older than the health workers who had just worked. This can be considered by management to review some policies regarding the loyalty of health workers.

\section{Level of Compliance Health workers Perform Handwashing at Surabaya "X" Hospital}

The results of the study prove that the level of compliance of health workers in washing their hands at "X" Hospital in Surabaya is $76 \%$ if it is adjusted to the category of compliance level of health workers doing hand washing by Perdalin, then the category of compliance level of health workers doing hand washing at "X" Hospital Surabaya is the maximum compliance $(>75 \%)$ when compared with the level of compliance of health workers doing hand washing in the United States (50\%) and Australia (65\%), the level of compliance of health workers doing hand washing in Surabaya "X" Hospital is also still more well.

\section{Knowledge of Health Workers About Hand washing with Compliance Level Health Workers Perform Hand washing at Surabaya "X" Hospital}

The results of the study prove that health workers with a high level of knowledge related to hand washing have a higher compliance $(54.7 \%)$ in carrying out hand washing procedures. As was stated by Notoatmojo (Notoatmodjo, 2010) where knowledge-based behavior will be more lasting than behavior that is not based on knowledge. Thus, in this situation, health workers who have a high level of knowledge about hand washing show their compliance with hand washing. 


\section{Level of Education Health Workers with Compliance Level Health Workers Do Handwashing}

The results showed that the highest level of compliance of health workers was in health workers with a Bachelor's degree (55.3\%). In accordance with Asmadi (Asmadi, 2008) where education influences individual thought patterns and thought patterns affect one's behavior. In this context health workers with Bachelor education are more obedient than health workers with Diploma III education.

\section{Age of Health Workers with Compliance Level Health Workers Do Handwashing}

The results showed the highest level of adherence was in health workers aged over 30 years (46.6\%). In line with the opinion of Peaget in Anwar, that someone at this age is more adaptable so that in carrying out a procedure more responsive and do it right. Inversely proportional to Robbins (Robbins, 2001) which states that someone younger tends to have a strong physique and can work hard but is less disciplined and less responsible at work.

The lowest compliance was at the age of $20-25$ years $(12.7 \%)$ directly proportional to Robbins (Robbins, 2001) which states that the positive qualities present in an older person include experience, consideration, strong work ethics, and commitment to quality (in this case a commitment to always wash hands according to standards). In this study older health workers were more compliant or vice versa younger health workers were less obedient.

\section{Duration of Work of Health Workers with Compliance Level Health workers do hand washing}

The results showed that, health workers with more than 10 years of service had the highest level of compliance (47.3\%), in line with Gibson (Gibson et al., 1996), the longer a person works the higher the level of achievement, high achievement comes from good behavior in this case good behavior for washing hands. In this study, health workers whose tenure was more than 10 years were more obedient than health workers whose tenure was less than 10 years.

\section{Relationship between Characteristics of Health Workers and Compliance Level Health workers perform handwashing at Surabaya "X" Hospital}

The results of this study prove that the characteristics of health workers with the level of compliance of health workers doing hand washing show a significant relationship. By research conducted by Taadi (Taadi et al., 2019) that there is a significant relationship between the level of knowledge about hand washing with the level of compliance of health workers doing hand washing and also by research conducted by Sulastri which states that there is a significant relationship between knowledge and length of work with the level of compliance of health workers doing hand washing, and knowledge and length of work are the variables that most determine compliance in washing hands.

Compliance can be influenced by internal and external factors such as age, education, knowledge and years of service supported by Notoadmodjo who argues that the factors that influence compliance are education, age, and motivation (Nurbaiti, 2007). From all the opinions of the experts, it is clear that it is true that the characteristics of health workers are related to the level of compliance of health workers in washing their hands. 


\section{CONCLUSION}

The results of the study prove that there is a significant relationship between the characteristics of health workers (knowledge, education, age, and years of work) with the level of compliance of health workers doing hand washing in Surabaya "X" Hospital. The level of compliance of health workers doing hand washing Surabaya "X" Hospital is included in the category of maximum compliance $>75 \%$.

The Surabaya "X" Hospital must re-evaluate the effectiveness of the hospital's nosocomial infection prevention program, especially regarding the compliance of health workers doing hand washing to improve the compliance of health workers doing hand washing at Surabaya "X" Hospital. All health professionals must increase their awareness to always work according to the main standard procedures for washing hands. For health workers who are still educated in diploma III, they should consider following up their education towards higher education so that their existence in health services in the current era of globalization can be maintained and improved. For health workers who have an undergraduate education but are still not compliant to wash their hands, they must change their attitudes so that they can become a role model for all health workers, especially for health workers who are still educated in diploma III. The next researcher might be able to research compliance with washing hands not based on the characteristics of health workers but hospital management or human resource management factors.

\section{ACKNOWLEDGMENT}

The authors thank all those who helped and contributed to the preparation of this research.

\section{REFERENCE}

Asmadi. (2008). Teknik Prosedural Keperawatan: Konsep dan Aplikasi Kebutuhan Dasar Klien. Salemba Medika.

Bujuri, D. A. (2018). Analisis Perkembangan Kognitif Anak Usia Dasar dan Implikasinya dalam Kegiatan Belajar Mengajar. LITERASI (Jurnal Ilmu Pendidikan), 9(1), 37. https://doi.org/10.21927/literasi.2018.9(1).37-50

Damanik, S. (2012). Kepatuhan Hand Hygiene Di Rumah Sakit Immanuel Bandung. EJournal Unpad, 683.

Darmadi. (2008). Infeksi Nosokomial: Problematika Dan Pengendaliannya. Salemba Medika.

Fesharaki, M. G., Rahmati-najarkolaei, F., \& Aghamiri, Z. (2014). Hand-Washing Compliance Rate and the Influencing Factors Hand-Washing Compliance Rate and the Influencing Factors. October. https://doi.org/10.5812/archcid.17316

Gibson, J. L., Ivancevich, J. M., \& Donnelly, J. H. (1996). Organization: Perilaku, Struktur, Proses Jilid 1-8/E. Binarupa Aksara.

Helder, O. K., Goudoever, J. B. Van, Hop, W. C. J., Brug, J., \& Kornelisse, R. F. (2012). Hand disinfection in a neonatal intensive care unit : continuous electronic monitoring over a oneyear period. 1-5. https://doi.org/10.1186/1471-2334-12-248

Iskandar, M. B., \& Yanto, A. (2018). Pengaruh Pendidikan Kesehatan terhadap Pelaksanaan Cuci Tangan 6 Langkah 5 Momen Keluarga Pasien di Ruang Rawat Inap RS Roemani Semarang dirawat, termasuk rumah sakit. Mencuci tangan merupakan rutinitas yang murah dan penting perkembangbiakan mikroorga. Prosiding Seminar Nasional Mahasiswa 
Unimus,

1 ,

$120-128$

http://prosiding.unimus.ac.id/index.php/mahasiswa/article/view/108/138

Kampf, G., \& Löffler, H. (2010). Hand disinfection in hospitals - benefits and risks. 2010(Band 8), 978-983. https://doi.org/10.1111/j.1610-0387.2010.07501.x

Larson, E., Silberger, M., Jakob, K., Whittier, S., Lai, L., Della Latta, P., \& Saiman, L. (2000). Assessment of alternative hand hygiene regimens to improve skin health among neonatal intensive care unit nurses. Heart and Lung: Journal of Acute and Critical Care, 29(2), 136-142. https://doi.org/10.1067/mhl.2000.104139

Lestari, A. O. A. W. (2019). Relationship Between Knowledge and Attitude To Hand. Jurnal Promkes: The Indonesian Journal of Health Promotion and Health Education, 7(1), 1-11. https://doi.org/10.20473/jpk.V7.I1.2019.1

Notoatmodjo. (2010). Ilmu Kesehatan Masyarakat Prinsip-Prinsip Dasar. In Rineka Cipta (pp. 57-65).

Nurbaiti. (2007). Ilmu Perilaku dan Tingkat Kepatuhan.

Paudel, I. S., Ghosh, V., \& Adhikari, P. (2017). Knowledge, Attitude and Practice of nursing students regarding hand hygiene Original Research Article Knowledge, Attitude and Practice of nursing students regarding hand hygiene in Western region of Nepal. January. https://doi.org/10.3126/jcmsn.v12i4.16417

Rikayanti, K. H., \& Arta, S. K. (2014). Hubungan Tingkat Pengetahuan dengan Perilaku Mencuci Tangan Petugs Kesehatan Di Rumah Sakit Umum Daerah Badung Tahun 2013. Community Health, II(1), 21-31.

Robbins;, S. P. (2001). PERILAKU organisasi: konsep kontroversi, aplikasi (ed. Bahasa). Prenhallindo.

Saragih, R., \& Rumapea, N. (2012). Hubungan Karakteristik Perawat Dengan Tingkat Kepatuhan Perawat Melakukan Cuci Tangan di Rumah Sakit Columbia Asia Medan. EJournal Universitas Darma Agung Medan. http://uda.ac.id/jurnal/files/7.pdf

Sharif, A., Arbabisarjou, A., Balouchi, A., Ahmadidarrehsima, S., \& Haddad, H. (2016). Knowledge, Attitude, and Performance of Nurses toward Hand Hygiene in Hospitals. 8(8), 57 65. https://doi.org/10.5539/gjhs.v8n8p57

Soeroso S. (2003). Manajemen sumberdaya manusia di rumah sakit. EGC.

Taadi, T., Setiyorini, E., \& Amalya F, M. R. (2019). Faktor yang Berhubungan dengan Kepatuhan Cuci Tangan 6 Langkah Moment Pertama pada Keluarga Pasien di Ruang Anak. Jurnal Ners Dan Kebidanan (Journal of Ners and Midwifery), 6(2), 203-210. https://doi.org/10.26699/jnk.v6i2.art.p203-210

Taherri, F. J. and E. Z. (2007). Nursing Studet and Staff Knowledge about Nosocomial Infection. Iranian Journal of Infectious Diseases and Tropical Medicine, 12(37), 83-86. 